\author{
ACTA MYCOLOGICA \\ Vol. 46 (2): 129-136 \\ 2011
}

\title{
Entoloma albotomentosum (Agaricales, Basidiomycota), a species new to Poland
}

\author{
MAREK HALAMA \\ Museum of Natural History, Wrocław University \\ Sienkiewicza 21, PL-50-335 Wrocław, marhalam@biol.uni.wroc.pl
}

Halama M.: Entoloma albotomentosum (Agaricales, Basidiomycota), a species new to Poland. Acta Mycol. 46 (2): 129-136, 2011.

The first record of Entoloma albotomentosum Noordel. \& Hauskn., a member of the subgenus Claudopus and section Claudopus, is reported from Poland. A full description and illustration of the species based on Polish specimens are given and its taxonomy, ecology, and general distribution are also provided.

Key words: Entolomataceae, Entoloma sect. Claudopus, pleurotoid habit, distribution, Oleśnica Plain, Polish mycobiota

\section{INTRODUCTION}

The genus Entoloma (Fr.) P. Kumm. - the second largest genus of Agaricales (after Cortinarius) is monophyletic (Co-David et al. 2009) and represented by at least 1000 species on a worldwide scale (Kirk et al. 2008). Although species of the section Claudopus Noordel. of the genus Entoloma are cosmopolitan, their basidiomata are often overlooked by researchers because of their small size or unusual habitats. Fungi from this section are generally characterized by a pleurotoid or omphalinoid, small basidiocarps and typically excentric, lateral or lacking stipe (Noordeloos 2004). They are saprotrophic, usually growing on dead organic matter such as rotten wood, bark, and various debris of grasses and sedges, and also on the ground, but some have been found to be parasites of other fungi (Cantharellus cibarius, C. lutescens, Coriolus versicolor, Xanthochrous perennis) and mosses (Sphagnum, Aulacomnium) (Noordeloos 1992, 2004). Just because of the pleurotoid (or crepidotoid) growth form, a lot of these species are sometimes placed in separate genus Caludopus Gillet. (Horak 1980; Largent et al. 2011). However, most authors consider the genus Caludopus artificial rather than natural, and place these fungi in subgenus Claudopus and section 

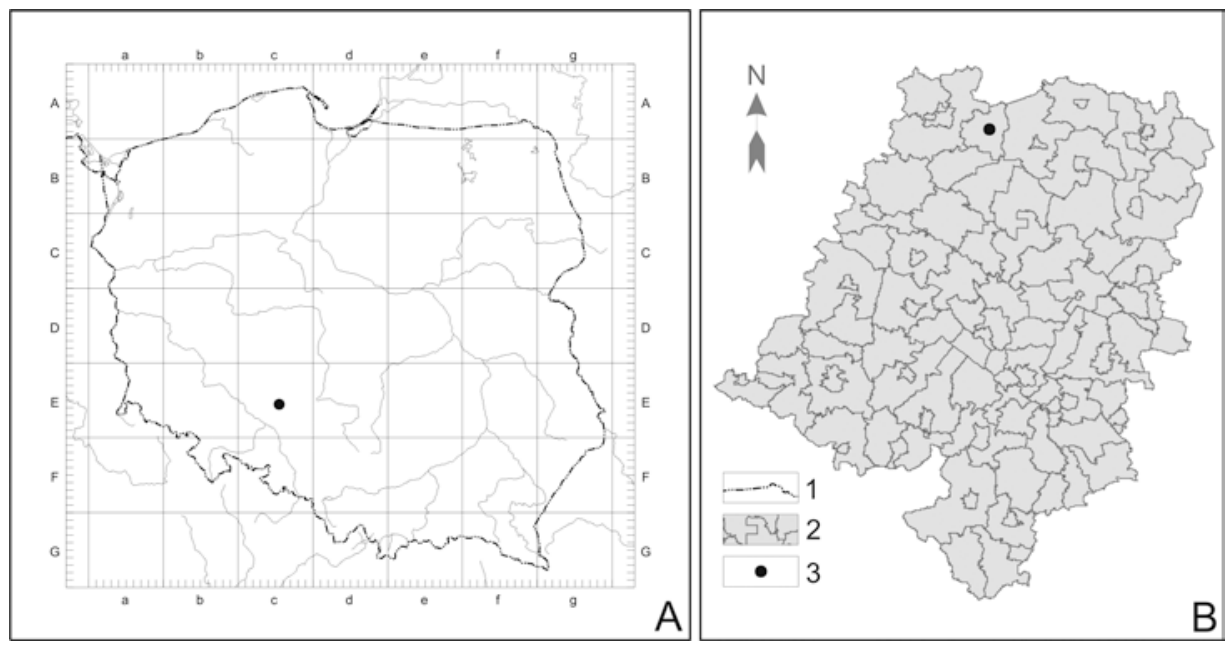

Fig. 1. The locality of Entoloma albotomentosum in Poland (based on a $100 \mathrm{~km}$ ATPOL grid) (A), and in the Opole Province (B): 1 - border of the country, 2 - administrative boundaries of the Opole Province, 3 - locality of the species.

Claudopus within the genus Entoloma (Noordeloos 1992, 2004), a concept favoured in this paper.

Out of 10 species belonging to the section Claudopus in Europe, so far no more than 5 species have been reported to occur in Poland: E. byssisedum (Pers.: Fr.) Donk, E. depluens (Batsch: Fr.) Hesl., E. jahnii Wölfel \& Winterhoff, E. ollare Ludwig \& Röbig and E. parasiticum (Quél.) Kreisel (Wojewoda 2003; Nita, Bujakiewicz 2006; Mleczko, Ociepa 2007; Nita, Bujakiewicz 2007; Kujawa 2009; Nita, Stefaniak 2010; Stefaniak 2010). During a period of damp summer weather in August 2010, unusual pleurotoid basidiocarps were found growing on dead, fallen reedgrass leaves in the area of post-agricultural land at Domaszowice, Oleśnica Plain (SW Poland; ATPOL: Ec-55; Fig. 1). Laboratory studies showed that they represent a very interesting member of the Claudopus section, Entoloma albotomentosum Noordel. \& Hauskn. According to the author's knowledge, this species has not been reported from Poland to date and the present collection is the first record in the country. E. albotomentosum is a rare species in many countries of Europe and very variable. For that reason a detailed description and illustrations are presented to facilitate identification of this fungus from further localities.

\section{MATERIAL AND METHODS}

The study is based on material gathered by the author in 2010 during the mycological research in the south-western Poland. The material was gathered within one locality. The samples were documented with colour photographs (partly shown on Fig. 2). The description of macroscopic features is based on fresh material, comprising 2 collections, 10 basidiomata in all stages of development. The microcharacters 

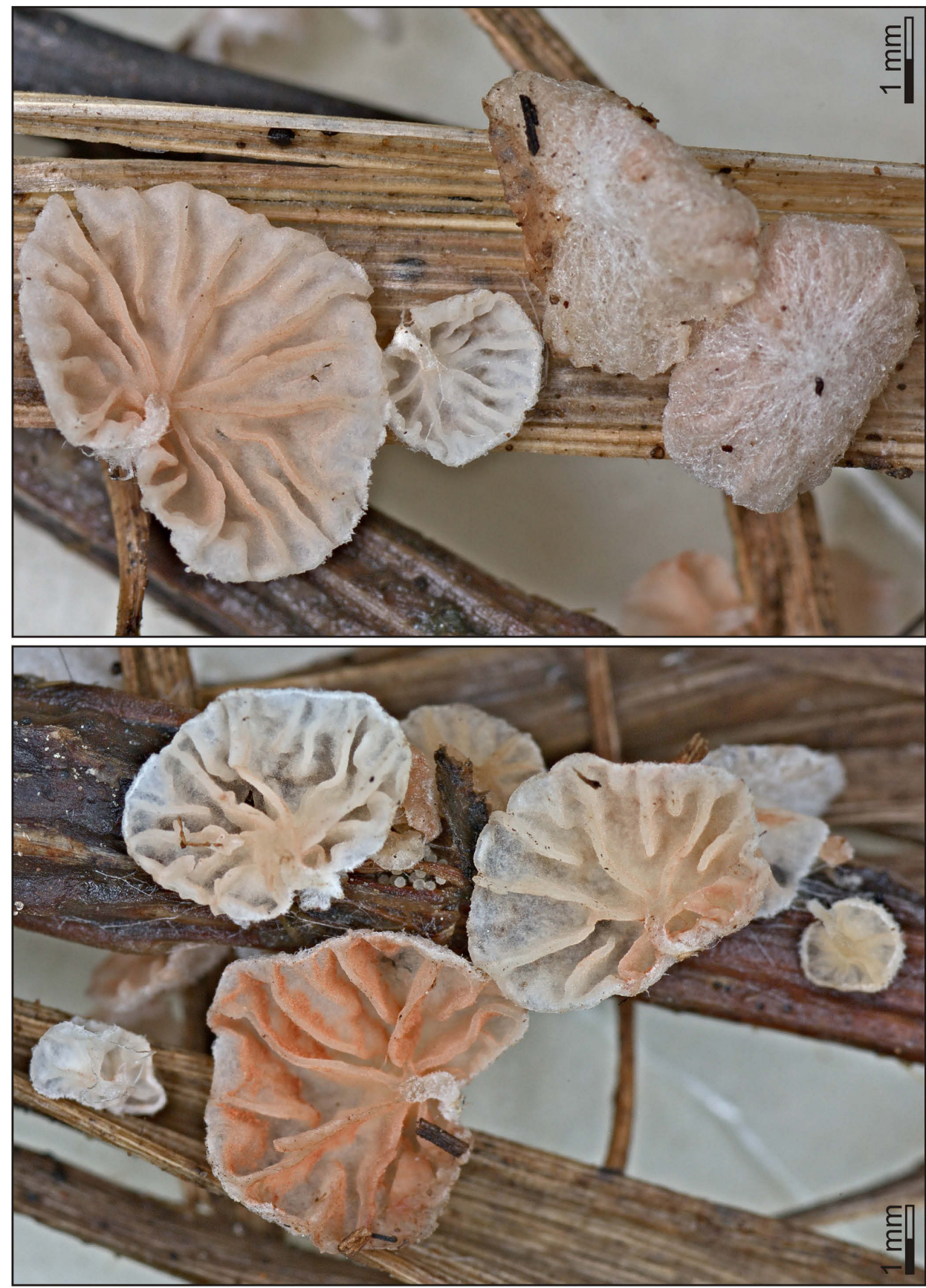

Fig. 2. Basidiocarps of Entoloma albotomentosum recorded at Domaszowice (coll. 14.08.2010; photo by M. Halama). 


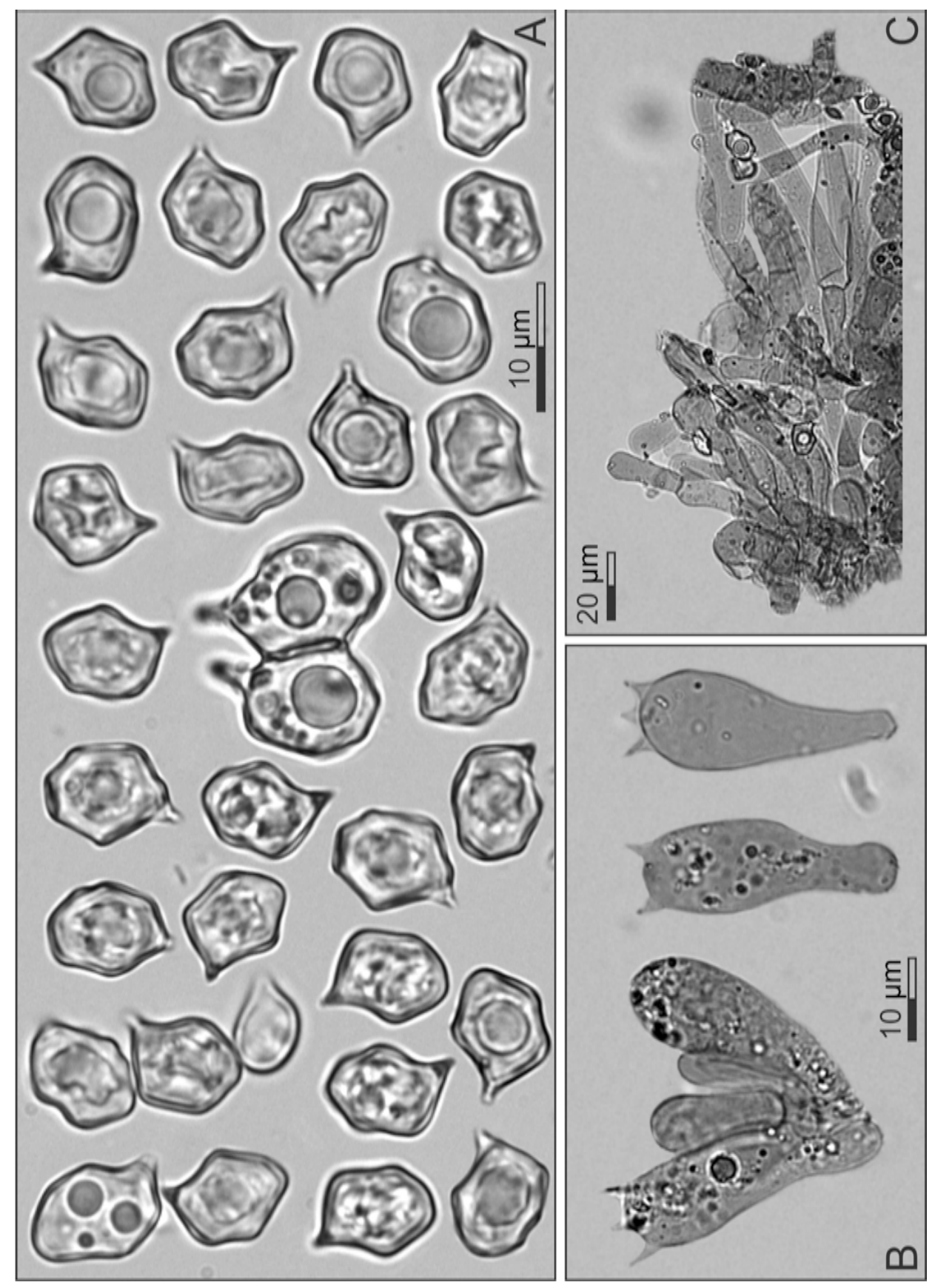

Fig. 3. Basidiospores (A), basidia (B), and hyphae of pileipellis (C) of Entoloma albotomentosum recorded at Domaszowice (coll. 14.08.2010). 
of 2 recorded basidiomata (from 2 collections) were observed and measured under a light microscope at $1500 \times$ (basidiospores) and $800 \times$ (other features). For microscopic observations, dried pieces of basidiomata were placed in $5 \% \mathrm{NH}_{4} \mathrm{OH}$ for about 1 minute, then transferred to tap water until they become pliable. Free-hand sections of the rehydrated pieces of basidiomata were examined in $5 \% \mathrm{NH}_{4} \mathrm{OH}$, Congo Red and in phloxine (in $1 \% \mathrm{NH}_{4} \mathrm{OH}$ ). Amyloidy was tested with Melzer's reagent. Morphological measurements were made and are presented according to the method used by Breitenbach \& Kränzlin (1991). The 95\% population limits for the mean were calculated and the lower and upper limits are presented. The minimum and maximum dimensions are given in parentheses additionally. The ratio of basidiospore length to its width (Q) was calculated. The length of basidia was measured excluding sterigmata. All statistical analyses were performed using Statistica software (version 8, StatSoft). Terminology of morphological and anatomical features has been adopted mainly from Vellinga (1988) and Noordeloos (1992). Reported size of basidiospores, basidia and pileipellis hyphae were based on 101, 31 and 31 measurements, respectively. Microphotographs were taken using Nikon DS.-Fi1 digital camera. The voucher specimens of E. albotomentosum have been deposited in WRSL (Museum of Natural History, Wrocław University, Wrocław, Poland).

\section{RESULTS AND DISCUSSION}

\section{Entoloma albotomentosum Noordel. \& Hauskn.}

Z. Mykol. 55(1): 32-33. 1989 - Entolomataceae, Agaricales, Agaricomycetidae, Agaricomycetes, Basidiomycota, Dikarya, Fungi (Hibbett et al. 2007). Icones: Noordeloos, Hausknecht (1989: 32-33); Noordeloos (1992: Tab. 72c; 2004: 13571358, fot. 324).

Basidiomata most often eccentric stipitate (Fig. 2). Pileus 1.5-5.4 mm broad, 0.5$1.5 \mathrm{~mm}$ deep, irregularly circular, initially convex to applanate with usually decurved margin, in old stage often somewhat applanate-depressed, and with undulating, \pm grooved marginal zone, not clearly hygrophanous, when expanding usually translucently striate, white, turning pinkish because of the colour of the lamellae, silvery white fibrillose when young, then, especially at centre with bundles of erect, agglutinated white hairs. Lamellae, $\mathrm{L}=5-14$, very distant, adnate to subdecurrent or decurrent, often thickened, vein-like, forked and sometimes anastomosing, white then pink with concolorous, entire edge. Stipe $0.6-2 \times 0.2-0.4 \mathrm{~mm}$, weakly to distinctly eccentric, often curved, white, covered with fine hairs, then glabrous, except for the base. Context very thin and delicate. Smell imperceptible. Basidiospores (7.23) 8.869.05 (12.14) × (5.89) 6.95-7.09 (8.87) $\mu \mathrm{m}, \mathrm{Q}=(0.97)$ 1.27-1.29 (1.64), 4-6-angled in side view, weakly pigmented, pale yellow (in $5 \% \mathrm{NH}_{4} \mathrm{OH}$ ), with a great guttule, inamyloid. Basidia (25.14) 28.86-30.55 (36.39) × (9.85) 11.75-12.64 (14.50) $\mu \mathrm{m}$, narrowly clavate, hyaline or containing small granules while immature, mostly with 4 sterigmata, without basal clamp. Lamella edge fertile. Pileipellis: a cutis with transitions to a trichoderm, made up of cylindrical to inflated, (3.41) 7.32-8.13 (12.01) $\mu \mathrm{m}$ wide hyphae; pigment absent. Clamps absent (Fig. 3). 
Material examined: 1. Poland, Domaszowice (Oleśnica Plain), idle rural land with scattered Betula and Calamagrostis, Rubus and Solidago in the field layer: on damp rotten leaf-sheaths and debris of herbaceous plants (Calamagrostis sp.), 14.08.2010, leg. M. Halama, WRSL; 2. Poland, Domaszowice (Oleśnica Plain), idle rural land with scattered Betula and Calamagrostis, Rubus and Solidago in the field layer: on damp rotten debris of herbaceous plants (Calamagrostis sp. ?), 17.08.2010, leg. M. Halama, WRSL.

Entoloma albotomentosum was described from Austria (Irnfritz: Teichholz) on rotten debris of grasses (Calamagrostis epigejos) and sedges (Carex) (Noordeloos, Hausknecht 1989). Since then it was rarely found in several other European countries, viz. the Netherlands, Liechtenstein, Germany, Denmark, England, Scotland and Norway (Krieglsteiner 2003; Legon et al. 2005; Arnolds, Veerkamp 2008; Noordeloos 2008). This species is distinctive among the European members of the section Claudopus mainly with its unique ecological requirements (occurrence on rotten leaf-sheaths and debris of grasses and sedges) (Noordeloos 2004), therefore some accessible data relating to its incidence on wood substrata seem to be doubtful (Musumeci 2005; Dechaume 2010). This fungus is regarded to be confined to damp woodlands or marshy places at edges of ponds (Noordeloos 1992; Krieglsteiner 2003; Legon et al. 2005). The recorded locality of E. albotomentosum in Oleśnica Plain offered some different moisture conditions, as the explored habitat was rather dry and never flooded. However, the collection from this site was made after prolonged rain, in places shaded by birches, on very damp debris of Calamagrostis.

The habit of the basidiocarps of E. albotomentosum oscillates between pleurotoid with reduced, lateral or lacking stipe, to omphalinoid with well-developed, sometimes central stipe (Noordeloos 1992, 2004). The Polish specimens of E. albotomentosum agree well macroscopically with the descriptions of Noordeloos \& Hausknecht (1989) and Noordeloos (1992, 2004, 2008). Microscopically, this collection shows some little differences in the spore size from the measurements presented by earlier authors (Tab. 1), but these discrepancies are probably attributable to the different sampling sizes. E. albotomentosum is similar in outward appearance to the species more widespread in Europe - Entoloma jahnii Wölfel \& Winterh., but is well separated morphologically as well as ecologically. It is distinguished primarily by the lack of clamps in all parts of basidiocarps and the lack of capitate pileo- and caulocystidia, and also smaller basidiospores. Moreover, the habitats of the two species are different, because E. jahnii is found in hidden places, such as the inner side of rotten bark and the underside of rotten wood of deciduous tree stumps and logs (Wölfel, Winterhoff 1993; Noordeloos 2004; Nita, Stefaniak 2010). Some superficial similarity has also Entoloma alliodorum Esteve-Rav., E. Horak \& A. Ortega with its white colour, but it differs generally by the more omphalioid habit (more distinct stipe), crowded lamellae, somewhat smaller, heterodiametrical basidiospores, strong smell of garlic and growing on mosses and rotten debris (Esteve-Raventós, Ortega 2003; Noordeloos 2004). There are also others non-European species, morphologically resembling E. albotomentosum in their pleurotoid, white basidiocarps, similarly shaped basidiospores, and lacking clamp connections. Entoloma pandanicola (E. Horak) Noordel. \& Co-David (from Papua New Guinea) can be distinguished primarily by habitat - rotting Pandanus leaves, farinaceous smell, adnexed to free lamellae and shorter (7-8 $\mu \mathrm{m}$ ) basidiospores (Horak 1980; Co-David et al. 2009), while 
Claudopus rupestris Largent \& Abell-Davis (from Australia) can be differentiated by its smaller, glistening-sticky, opaque, not translucently striate pileus (1-4 mm broad), adnexed - more ventricose lamellae, shorter (6.5-9.2 $\mu \mathrm{m})$ basidiospores, presence of pileocystidia, and habitat it grows on undersurface of small granite rocks (growing on thin to nearly non-existent soil layer with minute mosses) (Largent et al. 2011). E. albotomentosum reminds also small Crepidotus or even Clitopilus species. Some representatives of the mentioned genera are also found on debris of herbaceous plants (including the rotten leaf blades of grasses), however, E. albotomentosum can be easily distinguished from these crepidotoid or pleurotoid fungi by their basidiospores, which are globose, ovoid, ellipsoid, cylindrical to fusiform (smooth to rugose or verrucose or finely spiny) in Crepidotus, and ellipsoid or \pm amygdaloid and angular in polar view in Clitopilus.

Table 1

Comparison of the spore characteristics of E. albotomentosum according to different authors

\begin{tabular}{|c|c|c|c|}
\hline Authors & Spore length $(\mu \mathrm{m})$ & Spore width $(\mu \mathrm{m})$ & $\begin{array}{c}\text { Spore length/width } \\
\text { ratio }\end{array}$ \\
\hline $\begin{array}{c}\text { Noordeloos \& } \\
\text { Hausknecht }(1989), \\
\text { Noordeloos } \\
(1992,2008)\end{array}$ & $9.0-12.5$ & $6.5-8.0$ & $1.1-1.5$ \\
\hline Present studies & $\begin{array}{c}95 \% \text { population limits } \\
\text { for the mean } \\
(8.86-9.05)\end{array}$ & $\begin{array}{c}95 \% \text { population limits } \\
\text { for the mean } \\
(6.95-7.09)\end{array}$ & $\begin{array}{c}95 \% \text { population limits } \\
\text { for the mean } \\
(1.27-1.29)\end{array}$ \\
\hline
\end{tabular}

Recognized as a rare species, E. albotomentosum is red-listed in Austria (KrisaiGreilhuber 1999), Denmark (National Environmental Research Institute 2011), and in the Netherlands (Arnolds, Veerkamp 2008).

\section{CONCLUSION}

The infrequency of the species may be due to its small, inconspicuous basidiocarps, which are often hidden under mats or tufts of grasses and sedges, and therefore they are very difficult to find. That is also a possible reason why E. albotomentosum has only been recorded recently in Poland. This species is not well enough studied to make a statement about its rarity in Poland and further field studies are needed to determine a real condition and distribution of the species here.

Acknowledgements. I am indebted to the anonymous reviewer for valuable comments on the manuscript. I would like to thank Thomas Læssøe for his kind help with completing information on European distribution of E. albotomentosum. I also thank Katarzyna Dunaj for her assistance in collecting material. 


\section{REFERENCES}

Arnolds E., Veerkamp M. 2008. Basisrapport Rode Lijst Paddenstoelen. Nederlandse Mycologische Vereniging, Utrecht, $295 \mathrm{pp}$.

Breitenbach J., Kränzlin F. 1991. Fungi of Switzerland. 3. Boletes and Agarics ( $1^{\text {st }}$ Part). 3. Verlag Mykologia, Luzern, $364 \mathrm{pp}$.

Co-David D., Langeveld D., Noordeloos M.E. 2009. Molecular phylogeny and spore evolution of Entolomataceae. Persoonia 23: 147-176.

Dechaume J.-P. 2010. Base de données mycologique - Photos de Champignons: Entoloma albotomentosum Noordel. \& Hauskn. 1989. Published on the WEB site: http://www.mycodb.fr/photo. php?file=Entoloma_albotomentosum_2010_jd_1.jpg\&filter= [Accessed: 26-09-2011].

Esteve-Raventós F., Ortega A. 2003. Entoloma alliodorum, a new species of subgenus Claudopus with a garlic odour. Mycotaxon 86: 227-232.

Hibbett S.A., Binder M., Bischoff J.F., Blackwell M., Cannon P.F., Eriksson O.E., Huhndorf S., James T., Kirk P.M., Lücking R.H., Lumbsch T., Lutzoni F., Matheny P.B., Mclaughlin D.J., Powell M.J., Redhead S.A., Schoch C.L., Spatafora J.W., Stalpers J.A., Vilgalys R., Aime M.C., Aptroot A., Bauer R., Begerow D., Benny G.L., Castlebury L.A., Crous P.W., Dai Y.-C., Gams W., Geiser D.M., Griffith G.W., Gueidan C., Hawksworth D.L., Hestmark G., Hosaka K., Humber R.A., Hyde K.D., Ironside J.E., Kõljalg U., Kurtzman C., Larsson K.-H., Lichtwardt R., Longcore J., Mądlikowska J., Miller A., Moncalvo J.-M., Mozley-Standridge S., Oberwinkler F., Parmasto E., Reeb V., Rogers J.D., Roux C., Ryvarden L., Sampaio J.P., Schüßler A., Sugiyama J., Thorn R.G., Tibell L., Untereiner W.A., Walker C., Wang Z., Weir A., Weiss M., White M.M., Winka K., Yao Y.-J., Zhang N. 2007. A higherlevel phylogenetic classification of the Fungi. Mycological Research 111(5): 509-547.

Horak E. 1980. Entoloma (Agaricales) in Indomalaya and Australasia. Beihefte zur Nova Hedwigia. Beihefte zur Nova Hedwigia 65: 1-352.

Kirk P.M., Cannon P.F., Minter D.V., Stalpers J.A. 2008. Ainsworth \& Bisby's Dictionary of Fungi. $10^{\text {th ed }}$. $\mathrm{CAB}$ International, Wallingford, $771 \mathrm{pp}$.

Krieglsteiner G.J. 2003. Entolomataceae. (In:) G. J. Krieglsteiner (ed.). Die Großpilze Baden-Württembergs. 4. Ständerpilze: Blätterpilze. II. Verlag Eugen Ulmer GmbH \& Co., 4, Stuttgart: 138-243.

Krisai-Greilhuber I. 1999. Rote Liste gefährdeter Großpilze Österreichs. 2. Fassung. (In:) H. Niklfeld (ed.). Rote Liste gefährdeter Pflanzen Österreichs. 2. Auflage. Grüne Reihe des Bundesministeriums für Umwelt, Jugend und Familie 10, Wien: 229-266.

Kujawa A. 2009. Macrofungi of wooded patches in the agricultural landscape. I. Species diversity. Acta Mycol. 44 (1): 49-75.

Largent D.L., Abell-Davis S.E., Cummings G.A., Ryan K.L., Bergemann S.E. 2011. Saxicolous species of Claudopus (Agaricales, Entolomataceae) from Australia. Mycotaxon 116: 253-264.

Legon N.W., Henrici A., Roberts P., Spooner B.M., Watling R. 2005. Checklist of the British and Irish Basidiomycota. Royal Botanic Gardens, Kew, 536 pp.

Mleczko P., Ociepa A.M. 2007. Entoloma ollare, a species of subgenus Claudopus, new to Poland. Polish Bot. J. 52 (2): 159-163.

Musumeci E. 2005. Forum Micologico Natura Mediterraneo - Micologia: Entoloma albotomentosum Noordel. \& Hauskn. 1989. Published on the WEB site: http://www.naturamediterraneo.com/forum/ topic.asp?TOPIC_ID $=4524 \&$ whichpage $=1$ [Accessed: 26-09-2011].

National Environmental Research Institute. 2011. The Danish Red Data Book. Published on the WEB site: http://www2.dmu.dk/ [Accessed: 10-2011].

Nita J., Bujakiewicz A. 2006. Łęgi i olsy ostoją rzadkich i zagrożonych grzybów wielkoowocnikowych. (In:) Z. Mirek, E. Cieślak, B. Paszko,W. Paul, M. Ronikier (eds). Rzadkie, ginące i reliktowe gatunki roślin i grzybów - Problemy zagrożenia i ochrony różnorodności flory Polski. Materiały ogólnopolskiej konferencji naukowej, Kraków 30-31 maja 2006, Kraków, p. 111.

Nita J., Bujakiewicz A. 2007. Łęgi i olsy ostoją rzadkich i zagrożonych grzybów wielkoowocnikowych. Studia i Materiały Centrum Edukacji Przyrodniczo-Leśnej, R.9 - Zeszyt 2/3 (16): 519-529.

Nita J., Stefaniak M. 2010. Entoloma jahnii, a rare species in Europe. Acta Mycol. 45 (2): 157-162.

Noordeloos M.E. 1992. Entoloma s.l. Fungi Europaei. 5. Libreria editrice Giovanna Biella, Saronno, $1-760$.

Noordeloos M.E. 2004. Entoloma s.l. (Supplemento). Fungi Europaei. 5A. Edizioni Candusso, Alassio: 761-1378. 
Noordeloos M.E. 2008. Entoloma (Fr.) P. Kumm. (In:) H. Knudsen, J. Vesterholt (eds). Funga nordica. Agaricoid, boletoid and cyphelloid genera. Nordsvamp, Copenhagen: 433-491.

Noordeloos M.E., Hausknecht A. 1989. Über einige neue und interessante Rötlinge aus Österreich. Zeitschrift für Mykologie 55 (1): 31-42.

Stefaniak M. 2010.Mycocoenological investigations in the forest associations of Krajkowo Nature Reserve - preliminary results. (In:) W. Kurek, K. Marciszewska, A. Szczepkowski (eds). Proceedings of the 55th Meeting of the Polish Botanical Society "Planta in vivo, in vitro et in silico". Acta Societatis Botanicorum Poloniae, Warsaw: 78.

Vellinga E.C. 1988. Glossary. (In:) C. Bas, T.W. Kuyper, M. E. Noordeloos, E.C. Vellinga (eds). Flora Agaricina Neerlandica. Critical monographs on families of agarics and boleti occurring in the Netherlands. 1. A.A. Balkema Publishers, Rotterdam: 54-64.

Wojewoda W. 2003. Checklist of Polish larger Basidiomycetes. (In:) Z. Mirek (ed.). Biodiversity of Poland. 7. W. Szafer Institute of Botany, Polish Academy of Sciences, Kraków, 812 pp.

Wölfel G., Winterhoff W. 1993. Entoloma jahnii, ein neuer Holzbewohner. Österreichische Zeitschrift für Pilzkunde 2: 11-14.

\section{Entoloma albotomentosum (Agaricales, Basidiomycota), gatunek nowy dla Polski}

\section{Streszczenie}

W Polsce stwierdzono dotychczas występowanie 5 przedstawicieli sekcji Claudopus, rodzaju Entoloma (dzwonkówka), tj.: E. byssisedum, E. depluens, E. jahnii, E. ollare i E. parasiticum. Grzyby te charakteryzują się z reguły drobnymi owocnikami typu boczniakowatego (pleurotoidalnego) lub pępówkowatego (omfaloidalnego). Są wśród nich gatunki saprotroficzne, rozwijające się na różnych, butwiejących szczątkach roślin wyższych lub pojawiające się bezpośrednio na ziemi. Należą tu również gatunki patogeniczne, rozwijające się na owocnikach innych grzybów lub związane z obecnością mszaków. W trakcie obserwacji mikologicznych, przeprowadzonych w sierpniu 2010 roku w miejscowości Domaszowice (Równina Oleśnicka), znaleziono przypadkowo na terenie nieużytku porolnego kilka bardzo drobnych, białawo zabarwionych, pleurotoidalnych owocników, zasiedlających martwe szczątki traw (głównie butwiejące liście trzcinnika Calamagrostis sp.).

Badania laboratoryjne wykazały, iż reprezentują one nowy dla mikobioty Polski gatunek dzwonkówki - Entoloma albotomentosum Noordel. \& Hauskn. (proponowana polska nazwa: dzwonkówka ciżmówkowata). E. albotomentosum została opisana w 1989 roku z terenu Austrii. W najnowszych opracowaniach takson ten ujęty jest w podrodzaju i sekcji Claudopus. Gatunek ten cechuje się wytwarzaniem drobnych, niepozornych, biało zabarwionych i dość zmiennych w budowie makroskopowej owocników, które mogą mieć formę boczniakowatą (z trzonkiem wykształconym bocznie, zredukowanym bądź niewykształconym) lub pępówkowatą (z trzonkiem wyraźnie wykształconym i niekiedy centralnie osadzonym). W młodym stadium owocniki te zwykle przypominają do złudzenia niewielkich przedstawicieli rodzaju ciżmówka (Crepidotus). Według danych literaturowych E. albotomentosum pojawia się przede wszystkim w gęstych zaroślach traw i turzyc oraz na brzegach stawów, gdzie tworzy owocniki na butwiejących szczątkach traw i turzyc. Rozmieszczenie tego gatunku jest słabo poznane. Do chwili obecnej stwierdzono jego występowanie jedynie w Europie, gdzie (oprócz Austrii) znany jest on z rozproszonych stanowisk, zlokalizowanych w Holandii, księstwie Lichtenstein, Niemczech, Danii, Anglii, Szkocji i Norwegii.

Specyficzne preferencje siedliskowe oraz niewielkie rozmiary owocników E. albotomentosum są prawdopodobnym powodem rzadkości notowań tego gatunku w terenie. 
Dokładniejsze poszukiwania dają szansę na znalezienie dalszych stanowisk tego grzyba, $\mathrm{m}$. in. w Polsce. W prezentowanej pracy przedstawiono szczegółowy opis i ilustracje cech zebranych owocników E. albotomentosum. Przedstawiono również informacje na temat taksonomii, ekologii i rozmieszczenia tego gatunku. 